\title{
Comparative Study of Legal Protection for Migrant Workers in Participation of Social Security Programs in Indonesia and Singapore
}

\begin{abstract}
Nur Putri Hidayah ${ }^{1 *}$
${ }^{1}$ Faculty of Law, University of Muhammadiyah Malang, Malang, East Java, 65144 Indonesia.

* corresponding author: nurputri88@gmail.com

\begin{tabular}{|c|c|}
\hline Article Info & Abstract \\
\hline $\begin{array}{l}\text { Article History } \\
\text { Received: Mar 03, 2020; } \\
\text { Reviewed: Mar 05, 2020; } \\
\text { Accepted: Mar 06, 2020; } \\
\text { Published: Mar 31, } 2020 \text {. } \\
\text { DOI: } \\
\text { 10.22219/lijh.v28i1.11786 }\end{array}$ & $\begin{array}{l}\text { Social security is one of the basic rights of workers both local and migrant } \\
\text { workers as stated on Art. } 25 \text { Universal Declarations of Human Rights. The } \\
\text { enactment of single markets and production based in the era of ASEAN } \\
\text { Economic Community inevitably brings migrant workers particularly in } \\
\text { Indonesia and Singapore. This must be in line with a proper legal instruments to } \\
\text { protect migrant workers' rights in a social security participation. This study aims } \\
\text { to compare on how Indonesia and Singapore provide legal protection to migrant } \\
\text { workers in the social security participation and what social security programs that } \\
\text { can be followed in both countries. The research method used is a normative } \\
\text { research method with a statute approach. The result of the study shows that } \\
\text { Indonesia has provided protection for migrant workers the same way as local } \\
\text { workers as stated on Art. } 22 \text { Universal Declaration of Human Rights, whereas } \\
\text { Singapore only provides the social security to local workers. Migrant workers get } \\
\text { the protection through other ways, namely insurance and bilaterall multilateral } \\
\text { agreements. For the social security programs followed by migrant workers, both } \\
\text { Indonesia and Singapore do not provide the programs related to what has been } \\
\text { regulated on Art. } 25 \text { Universal Declaration of Human Rights. }\end{array}$ \\
\hline
\end{tabular}
\end{abstract}

(C)2020; This is an Open Acces Research distributed under the term of the Creative Commons Attribution Licencee (https://Creativecommons.org/licences/by/4.0), which permits unrestricted use, distribution, and reproduction in any medium, provided the original works is properly cited.

\section{INTRODUCTION}

The era of ASEAN Economic Community (MEA), which began in late 2015, inevitably brings massive migrant workers in ASEAN. Based on Article 3 the ASEAN Consensus on The Protection and Promotion of the Right of Migrant Workers, Migrant workers are people who work abroad and are paid for in a country they are working. This is because one of the MEA pillars, namely Single Market and Production Based which is achieved through freedom from the influx of migrant workers in ASEAN (The Asean Secretariat 2015). In Indonesia, in 2017 there was an increase of 69.85 percent of migrant workers compared to 2016 (Gumelar 2018). 
This is a remarkable and the highest number in Indonesia. This is contrary to Singapore which is in the 3rd place of the highest income per capita level (Governance \& Sosial Development Research Center 2011), Singapore is the highest average wages country in ASEAN. At least in 2017, when Indonesia paid workers for only an average of Rp.3,600,000/month, Singapore had paid 10 times bigger which was Rp.35.800,000/month (Setiawan 2018).

The migration of migrant workers must be faced by ASEAN countries to be ready to equip the basic rights of migrant workers. One of them is by participating in social security program. It is a form of social protection that becomes a country's responsibilities to guarantee all workers in fulfilling the basic needs of a decent life (Triyono \& Soewartoyo 2013). The purpose is to provide an access to healthcare security and guarantee the income, minimum income for those who need it and adequate income substitutes for those who have contributed based on their level of income (International Labour Organiation 2008).

Moreover, social security has broad implications in life. This implication is augmented by socio-economic forces that continually form an environmental stability (Brown, Kapteyn, \& Mitchell 2016). The existence of social security can increase life expectancy and population growth. Therefore, the need for social security planning has become more important (ASSA 2014).

The protection of the world against migrant workers in the social security participation is regulated on Universal Declaration of Human Rights (UDHR). It was explained that basically people (regardless of citizenship) has the rights to social security. Based on article 22 UDHR, The social security is important because it is one of the keys to maintain dignity as a human being. Based on article 25 paragraph (1) UDHR, The social securities provided are in the form of health insurance, the right to food, clothes and shelter, guaranteed when he is unemployed, disabled, old age, widows/widowers, and other conditions which make lack of income beyond his control.

The right to access social security for migrant workers stated on Universal Declaration of Human Rights indicates that the social security participation for migrant workers is important and cannot be underestimated by the implementation of the norm. Considering the importance of social security and Indonesia and Singapore are also ASEAN countries that are preparing to face large-scale migration of migrant workers, it is important to examine on: 1) how do Indonesia and Singapore provide legal protection for migrant workers in social security participation, 2) what social security programs are prepared by Indonesia and 
Singapore for migrant workers who work in their countries, and 3) how adequate legal protection is provided according to Universal Declaration of Human Rights and ASEAN Consensus on The Protection and Promotion of The Rights of Migrant Workers?

Previously, there have been several studies conducted on employment themes both in Singapore and Indonesia. First, the article entitled Social Protection in Singapore written by Mukul G. Asher and Revathi Rajan (Asher \& Revathi 2018), stated that the social security system in Singapore, which at the time of the study was conducted, it was a country with a very rapid development. According to him, the government needs to side-track his focus from the housing and education sector to the health sector.

Second, an article entitled Assets or commodities? Comparing regulations of placement and protection of migrant workers in Indonesia and the Philippines written by Dinita Setyawati (Setyawati 2013), discussed about the legal protection of migrant workers in Indonesia and the Philippines by comparing Act No. 13 of 2003 which is applied in Indonesia with Republic Act (RA) No. 10022 which is applied in the Philippines. According to him, compared to the Philippines, Indonesia has a lower scheme for protecting migrant workers, especially in terms of education to workers and the responsibilities of government agencies.

Third, policy briefs entitled Social Security and Labour Migration in ASEAN written by Gloria, O Pasadilla (Pasadilla 2011), stated that social security portability influences the main decisions of migrant workers, for example, whether to retire early and where to retire - in the origin country or hosting home.

From the previous research, there are limited research that has been conducted on how Indonesia and Singapore providing legal assistance to workers in the participation of social security and the types of social security concrete programs provided for workers in Indonesia and Singapore. So, this study aimed to answer that condition, about how Indonesia and Singapore providing legal assistance to workers in the participation of social security. Contribution of this research results can be used as material for the governments of Indonesia and Singapore to conduct evaluations and efforts to strengthen legal protection of foreign workers in social security participation. 


\section{METHOD}

The research method used was a normative (Soekanto 2006). The purpose of this study was to find out how Indonesia and Singapore provide legal protection for migrant workers in the participation of social security and the types of social security concrete programs to protect them both in Indonesia and Singapore.

The nature of this research was descriptive (Soekanto 2006). A statute approach was used to answer the statement problem (Marzuki 2010). Based on the source, the type of the data used was a secondary data which includes legislation, books, scientific articles and journals, dictionaries, etc (Soekanto 2006). In detail, the secondary data used consisted of primary legal materials, secondary legal materials and tertiary legal materials.

RESULTS AND DISCUSSION

Legal Protection and Social Security Program of Migrant Workers' Participation in Social Security Based on Universal Declaration of Human Rights

Generally, there is no difference between the rights of local and migrant workers, and all workers are entitled to social security as stated on Art. 22 Universal Declaration of Human Rights. To guarantee it, the protection of workers' rights including the right to become participant in social security can be given both in the form of national efforts (legislation) and international cooperation (bilateral and multilateral).

The emphasis on protection of the participation in social security for migrant workers actually is provided in both countries, the origin and recipient countries . The origin country of migrant workers can form a regulation which can essentially protect the workers from fraud (from sending agents) or discrimination at the workplace. If in the recipient countries have no special protection for the participation in social security, the origin country will conduct a bilateral and multilateral cooperation with the recipient countries (Levitt et al. 2017). However, the recipient countries can form national regulations on protection and justice for migrant workers to get their rights to participate in social security.

The rules regarding the minimum program that must be given by the country to the workers, including migrant workers in social security programs are regulated on Art. 25 (1) Universal Declaration of Human Rights. They include: 1) health insurance, 2) food, clothes and shelter, 3) guaranteed when he is unemployed, 4) 
guaranteed when he is disabled, 5) guaranteed when they are at old age (or other conditions when he is unable to work).

\section{Legal Protection for Migrant Workers in Social Security Participation in} Indonesia and Singapore

\section{a. Indonesia}

In Indonesia, manpower is regulated on Act No. 13 of 2003 pertaining Manpower. In particular, the regulation on social security is currently regulated in Act No. 40 of 2004 pertaining National Social Security System (SJSN). For the implementing agencies, it is regulated in Act No. 24 of 2011 pertaining Social Security Organizing Agency. The implementing rules related to the National Law Social Security System (UU SJSN) and Social Insurance Administration Organization Act (UU BPJS) are regulated in Republic of Indonesia Presidential Regulation Number 12 of 2013 pertaining Health Insurance and Presidential Regulation Number 109 of 2013 pertaining Stages of Participation in Social Security Programs.

Legal protection for migrant workers, especially in the participation of social security has been regulated in such a way as outlined in Indonesian positive law (Zulfikar et al. 2018). The participation of social security for migrant workers has been regulated through the scope of anyone who can become a social security participant. In Article 1 Section (4) of the BPJS Act, it is stated that "Participants are persons including migrants who work for at least 6 (six) months in Indonesia who have paid contributions". This means that there are no differences in the subject of social security participants in Indonesia. The emphasis is only on payment of contributions. Contribution is a number of money paid regularly by participants, employers and/or the government. Even if they cannot afford to pay contributions, through Article 1 (7) of the BPJS Act, it will be paid by the government.

The participation of migrant workers' social security is reaffirmed even as an obligation on Article 14 of UU BPJS which "Every person including migrants who work for a minimum of 6 (six) months must be a participant in the social security program". For migrant workers who come and work, the registration of membership in social security becomes the obligation of employers as regulated on Article 15 of BPJS Act. Furthermore, the country provides opportunities for migrant workers to become participants in all social security programs held in Indonesia.

The participants in the social security program are not only for migrant workers who work in Indonesia but also their family members (Widodo \& Belgradoputra 2019). This has been regulated on Article 15 Section (2) of BPJS Act, which the data for the participants provided is not only the personal data of the employer and employee but also family members including the change. 
Legal protection for the participation of social security for migrant workers applied by Indonesia is increasingly complete with sanctions against the obligation to register social security participation as regulated on Article 15 Section (2) of BPJS Act. For the employers who do not register for social security participation, based on Article 17 (1) BPJS Act can be a subject to administrative sanctions. The administrative sanctions based on Article 17 (2) can be in the form of:

1) Written warning.

2) Fines and/or

3) No access to particular public service.

Sanctions in the form of written warning and fines are imposed by BPJS, while the other sanctions are carried out by local government on requests from BPJS.

Indonesia seriously applies the sanctions to employers who try to neglect their obligations to the rights of migrant workers in social security participation. The President through Government Regulation Number 86 of 2013 pertaining Procedures for Imposing Administrative Sanctions to Employers In Addition to State Administrators and Every Person Unless Employers, Workers and Recipients of Contribution Assistance in the Implementation of Social Security, issued regulations on implementing those sanctions.

Because of the employer probably will not deposit the contributions from the worker to BPJS, the country regulates it as a criminal act through the Article 55 of BPJS Act with the maximum threat of 8 (eight) years in prison or a maximum fines of Rp. 1,000,000,000 (one billion rupiah).

All of the above provisions show the serious priority of the Indonesian government to protect the rights of migrant workers in the participation of Social Security. It is not only forming nomenclature of legislation in the level of constitution but also in the level of implementing both in government regulations and others. In addition, an administrative and punishment sanctions show that these are frighten norm (restrictions without sanctions) so that they have the right authority to carry out.

\section{b. Singapore}

Generally, regulations regarding employment in Singapore are regulated in the Employment Act. Particularly, regulations of migrant workers in Singapore are regulated in the Employment of Foreign Manpower Act (EFMA). EFMA regulates the regulation and enforcement of work passes and offenses. Migrant workers in Singapore are divided into 2 (two) categories,(Governance \& Sosial Development Research Center 2011) namely: 
1) Foreign Talents

Foreign talents are migrant workers who have professional qualifications or have a higher education level.

2) Foreign Workers

Foreign workers are those who have a little expertise or even no expertise, who work in manufacturing, construction and domestic sectors. Foreign workers are the most in Singapore. They are inseparable from bilateral agreements regulated by Singapore government with India, Bangladesh, Sri Lanka, the Philippines and Thailand.

Unfortunately, both the Employment Act and EFMA do not regulate concretely and decisively the rights of social security participation for migrant workers. EFMA through Article 25 Paragraph (6) alphabet (c) EFMA, regulates the obligation of the controller to equip migrant workers with health insurance only. When the Employment Act was even revised in 2018 and effectively applied on April 1, 2019, there was no revision to the law at all about social security for migrant workers (Changes to the Employment Act 2018). Likewise for workplace accidents, both the Employee Act and EFMA do not regulate the rights of migrant workers to become participants in social security for workplace accidents. However, when the accident happened, the workers will get "workplace accident compensation" as regulated on Work Injury Compensation Act (WICA). The compensation is provided by the employer without following a social security or insurance scheme (Mahidol Migration Center 2011).

In addition, legal protection for the participation of migrant workers in Singapore is carried out through bilateral agreements between sending countries and Singapore as the recipient country. One of the countries that entered into a bilateral agreement to protect migrant workers in social security participation is Indonesia and Singapore. Bilateral cooperation is regulated through a Memorandum of Understanding between The supervisory board of the Workers Social Security Agency or BPJS Ketenagakerjaan and the Ambassador of Republic of Indonesia by organizing protection program for Indonesian migrant workers in Singapore (Subiyanto 2017). The legal basis used by Indonesia to claim cooperation with Singapore is the Minister of Manpower Regulation Number 7 of 2017 pertaining the Indonesian Workers' Social Security Program.

\section{Legal Protection of Migrant Workers' Participation in Social Security in Indonesia and Singapore Refers to Universal Declaration of Human Rights.}

Based on Art. 22 Universal Declaration of Human Rights, there must be no difference between the rights of local and migrant workers, and all workers are entitled to social security. However, Art. 22 Universal Declaration of Human Rights 
does not limit the cooperation in the form of bilateral and multilateral as a protection against the social security for migrant workers.

Based on the above explanation regarding legal protection of migrant workers in social security participation, only Indonesia which provides an equal rights between local and migrant workers in social security participation, while Singapore does not. Indonesia through Act No. 13/2003 pertaining Manpower, Act No. 40/2004 pertaining the SJSN and Act No. 24/2011, Indonesia protects the rights of migrant workers to participate in social security participants. Whereas in Singapore, it is not regulated both in the Employment Act and EFMA that migrant workers have the right to become social security participants in Singapore (only Singapore citizens and permanent residents of Singapore). However, Singapore is trying to provide protection through bilateral agreements between the countries, one of them is Indonesia. The disadvantage is if the origin country of migrant workers has not entered into bilateral or multilateral cooperation, the migrant workers have no right to become social security participants.

\section{Social Security Programs that could be Followed by Migrant Workers in Indonesia and Singapore}

\section{a. Indonesia}

The participation of social security as stated on Article 14 of BPJS Act is an obligation for migrant workers who work for a minimum of 6 (six) months in Indonesia. The registration of participation in social security is carried out by the employer.

The social security program that can be followed by migrant workers is explicitly regulated on Elucidation of Article 15 of BPJS Act, whereby migrant workers can become a participant in 5 (five) social security programs either organized by BPJS Kesehatan or BPJS Ketenagakerjaan. The types of social security programs regulated on Article 18 of SSJN Act which include health insurance, work accident insurance, old age insurance, life insurance and pension benefits.

1) Health Insurance

Health insurance based on Article 19 (2) of SJSN Act is held to ensure each participant receives health and maintenance benefits for their health needs. Health insurance is organized nationally based on the principle of social insurance and equity. Health insurance is organized by BPJS Kesehatan. Before BPJS Act was regulated, health insurance was organized by Health Insurance (Askes) and Workers' Social Security (Jamsostek). 
The participation of health insurance is not only migrant workers but also their families (wives/husbands, biological/stepchildren) of 5 (five) people maximum. For migrant workers who receive wages, the contributions are paid from deductions from workers' wages and additional contributions from the employers. However, for the recipients of contributions, health insurance is paid by the country.

2) Work Accident Insurance

Workplace accident insurance based on Article 29 Section (2) of SJSN Act is a social security held to ensure the participants receive health service benefits and cash compensation if they get an accident or have any illnesses because of working. The insurance is held nationally based on the principle of social insurance. Protection against the risk of workplace accidents is started since they go from home, they come back to home, and they work or do an official travel. Currently, the insurance is organized by BPJS Ketenagakerjaan (BPJS Ketenagakerjaan 2017b).

The participation of workplace accident insurance is only for migrant workers (not the family members).

3) Old age Insurance

The old age insurance based on Article 35 Section (2) of SJSN Act is held to ensure the participants receive cash if they have been old, remained permanently disabled, or died. The insurance is held nationally based on the principle of social insurance or mandatory savings. The organizer of this insurance is BPJS Ketenagakerjaan.

The participation of this insurance is the migrant workers (without family). The benefits are in the form of cash which is the accumulated of contributions and the results of development.

4) Pension Benefits

Pension benefits based on Article 39 Section (2) of SJSN Law is to maintain the life when the participants lose or decrease their income due to retirement age or permanent total disability. Pension benefits is held based on definite benefits and the principle of social insurance or mandatory savings. The insurance is held by BPJS Ketenagakerjaan.

The participation of pension insurance is the migrant workers (without family members). The benefits are maintaining a decent life and after experiencing disability. The benefits can be received regularly until $40 \%$ of wages (BPJS Ketenagakerjaan 2017a).

5) Life Insurance

Life Insurance based on Article 43 Section (2) of UU SJSN is held to provide death contributions which are given to the heirs. It is held nationally 
based on the principle of social insurance. Currently, the organizer of this insurance is BPJS Ketenagakerjaan.

The participation of this insurance is migrant workers (without family). The insurance provides benefits in the form of cash given to the heirs when participants die not due to workplace accidents.

\section{b. Singapore}

The social security executive in Singapore is The Central Provident Fund (CPF). The CPF was firstly established in 1955 as a state-funded pension, currently the scheme offered has been increased, not only the pension fund scheme, funded by the British colonial government. CPF contributions are paid by workers and employers. The CPF has evolved into a comprehensive social security system for retirement, health care, home ownership; family protection and asset purchases. The object of CPF participation is all Singaporean workers (Singapore citizens and permanent residents of Singapore) except migrant workers and domestic workers (Sosial Protection.org. n.d.). Even though the migrant workers have obtained legal permission to work in Singapore, they still cannot become CPF social security participants (Edward 2008).

The explanation above shows that Singapore does not provide social protection to workers through the CPF. To be protected, the Singapore government requires workers to become insurance participants. Based on Article 25 paragraph (6) alphabet (c) EFMA, the minimum of participation that must be fulfilled is health insurance.

The Singapore Ministry of Manpower provides medical insurance requirements financed by employers to workers who have work permits. The employer is obliged to buy and pay off the health insurance in a minimum period of 12 months or may be shorter if the years of service is less than 12 months (Ministry of Manpower Singapore 2010).

Whereas for the workplace accidents happened, there is also no social security program that can be followed. However, based on WICA, migrant workers will receive a direct compensation from the employer for the workplace accidents. Based on Art. 3 (1) WICA, workplace accidents that will be paid by compensation are calculated from the time the migrant worker goes to the workplace. The compensation paid is getting an accident when they are going to the workplace (Art. 3 WICA), getting sick at the workplace (Art. 4 WICA), getting accidents in the workplace which make a temporary and permanent disability (Art. 14 WICA), to getting workplace accidents which make them died (Art. 6 WICA). 
For Indonesian migrant workers, the protection is provided through BPJS . The programs that can be followed are as follows: 1) workplace accident insurance, 2) life insurance, 3) pension benefits. Work accident insurance and death insurance are mandatory, while pension benefits is optional (BPJS Ketenagakerjaan 2018). For migrant workers from other countries, social security programs are followed depending on the contents of bilateral agreements between the origin countries and Singapore government.

\section{The Social Security Program Provided to Migrant Workers in Indonesia and Singapore Based on the Universal Declaration of Human Rights}

The minimum social security program that must be given by the country is including migrant workers in social security. The social security program is involved in Art. 25 (1) Universal Declaration of Human Rights. The social security programs include: 1) health insurance, 2) food, clothes and shelter, 3) guaranteed when he is disabled, 4) guaranteed when they are disabled, 5) guaranteed when they are at old age (or other conditions that cause he is unable to work).

Based on the explanation above regarding social security programs that can be followed by migrant workers in Indonesia and Singapore, it can be concluded that both Indonesia and Singapore do not provide programs that are in accordance with what has been regulated on Art. 25 Universal Declaration of Human Rights. Indonesia provides social security programs in the form of health insurance, old age insurance, work accident insurance, life insurance and pension benefits to migrant workers. While Singapore does not provide any social security programs for migrant workers, it does require employers to equip migrant workers with health insurance and protection through WICA to compensate for workplace accidents experienced by migrant workers.

\section{CONCLUSION}

Indonesia has provided protection for migrant workers the same way as local workers, as regulated on Art. 22 Universal Declaration of Human Rights. The protection provided by Indonesia through Act No. 13/2003 pertaining Manpower, Act No. 40/2004 pertaining SJSN and Act No. 24/2011 pertaining BPJS. However, Singapore only provides the social security participation to local workers. Migrant workers get protection through other forms, namely insurance and bilateral/multilateral agreements.

Whereas, regarding the social security program followed by migrant workers, both Indonesia and Singapore do not provide programs that are in accordance with what has been regulated on Art. 25 Universal Declaration of Human Rights. Indonesia 
provides social security programs in the form of health insurance, old age insurance, work accident insurance, life insurance and pension benefits to migrant workers. Whereas Singapore does not provide any social security programs, but it requires employers to equip migrant workers with health insurance and compensation for workplace accidents.

\section{REFERENCES}

Asher, Mukul G., and Revathi. 2018. "Sosial Protection in Singapore." Friedrich Ebert Stiftung: 231-68. http://library.fes.de/pdf-files/iez/01443007.pdf.

ASSA. 2014. "ASSA Welcome Board.” ASSA. https://www.asean-ssa.org.

BPJS Ketenagakerjaan. 2017a. "Pension Insurance." BPJS Ketenagakerjaan. https://www.bpjsketenagakerjaan.go.id/Jaminan-Pensiun.html.

- 2017b. "Workplace Accident Insurance." BPJS Ketenagakerjaan. https://www.bpjsketenagakerjaan.go.id/Jaminan-Kecelakaan-Kerja.html.

—. 2018. "Indonesian Migrant Worker." BPJS Ketenagakerjaan. https://www.bpjsketenagakerjaan.go.id/pekerja-migran-indonesia.html. (January 12, 2019).

Brown, J. R, A Kapteyn, and O. S Mitchell. 2016. "Framing and Claiming: How Information- F Raming Affects Expected Social Security Claiming Behavior." Journal of Risk and Insurance 83(1): 139-62.

"Changes to the Employment Act." 2018. https://www.gov.sg/microsites/budget2018/press-

room/news/content/changes-to-the-employment-act (December 29, 2018).

Edward, Tamagno. 2008. Strengthening Social Protection for ASEAN Migrant Workers through Social Security Agreement. https://www.ilo.org/asia/publications/WCMS_160332/lang--en/index.htm.

Governance and Sosial Development Research Center. 2011. "Helpdesk Research Report: Sosial Protection System in Singapore." Governance and Sosial Development Research Center: 1-12. http://gsdrc.org/docs/open/hdq766.pdf.

Gumelar, Galih. 2018. "The Overwhelming Majority of Foreign Workers from China." CNN Indonesia. https://www.cnnindonesia.com/ekonomi/20180306201957-92-

280945/jumlah-tenaga-kerja-asing-membludak-mayoritas-dari-china. (April 24, 2018).

International Labour Organiation. 2008. Social Protection-New Concensus. Jakarta: International Labour Organiation.

Levitt, Peggy, Jocelyn Viterna, Armin Mueller, and Charlotte Lloyd. 2017. "Transnational Social Protection: Setting the Agenda." Oxford Development Studies 45(1): 2-19. 
Mahidol Migration Center. 2011. "Migrant Workers' Right to Social Protection in ASEAN: Case Study of Indonesia, Philiphines, Singapore and Thailand." http://www.social-

protection.org/gimi/RessourceDownload.action?ressource.ressourceId=27722. (December 20, 2018).

Marzuki, Peter Mahmud. 2010. Law Research. 6th ed. Jakarta: Kencana.

Ministry of Manpower Singapore. 2010. "Circular to Employer on Foreign Worker Medical Insurance." http://www.mom.gov.sg/Documents/highlights/FWMI Circular \%28Final\%297 Sep 07_FW.pdf. (December 23, 2018).

Pasadilla, Gloria O. 2011. "Social Security and Labor Migration in ASEAN." Asian Development Bank. http://hdl.handle.net/11540/4077 (December 3, 2018).

Setiawan, Yudha. 2018. "Singaporean Workers Receive the Highest Wages in ASEAN." Arah.com. https://www.arah.com/article/35/pekerja-singapuraterima-upah-tertinggi-di-asean.html (April 25, 2018).

Setyawati, Dinita. 2013. "Assets or Commodities? Comparing Regulations of Placement and Protection of Migrant Workers in Indonesia and the Philippines." Austrian Journal of South-East Asian Studies 6(2): 264-80.

Soekanto, Soerjono. 2006. Introduction of Law Research. Jakarta: Universitas Indonesia Publisher (UI Press).

Sosial Protection.org. "Singapore-Sosial Protection Platform." http://www.sosialprotection.org/gimi/RessouarcePDF.action;jsessionid=Lb0DOKrEMWRwD8 SbbwfLHcea_MFPqxFjY_rWwE4yd9bFU8zL6zOY!-1017928187?id=53116. (August 20, 2018).

Subiyanto, Rachmad. 2017. "BPJS TK MoU with Indonesian Embassy in Singapore for the Protection of Migrant Workers." http:/ / finansial.bisnis.com/read/20171209/215/716765/bpjs-tk-mou-dengankbri-singapura-untuk-perlindungan-pekerja-migran. (August 25, 2018).

The Asean Secretariat. 2015. A Blue Print for Growth: Asean Economic Community 2015: Progress and Key Achievement. Jakarta: ASEAN.

Triyono, and Soewartoyo. 2013. "The Obstacles to Participation in Social Security Programs for Workers in the Informal Sector: Case Study in Surabaya City." PRIORIS Law Journal 3(3): 26-41.

Widodo, Hartono, and R. Jossi Belgradoputra. 2019. "Perlindungan Pekerja Migran Indonesia." Binamulla Hukum 8(1): 107-16.

Zulfikar, A., S. Sukananda, H. Baharuddin, and S Sampara. 2018. "Harmonization of International Law in Indonesian Legal System: The Study of Indonesian Migrant Workers Protection Overseas.” OSF. 